\title{
Effect of NPSZn and Nitrogen Rates on Yield and Yield Components of Maize (Zea mays L) in Eastern Hararghe, Ethiopia
}

\author{
Jifara Gudeta, Zeleke Legesse and Alemayehu Biri \\ Oromia Agricultural Research Institute (IQQO); Fadis Agricultural research center, \\ P.O.Box $=904$, Harar, Ethiopia
}

\begin{abstract}
Maize (Zea mays L) cannot produce maximum yields unless sufficient nutrients are available. There are a number of factors which are responsible for the low production and productivity of maize. Among these factors, inappropriate crop nutrition management and poor soil fertility are the most important factors responsible for low yield of maize. When the soil does not supply sufficient nutrients for normal plant growth, application of supplemental nutrients are required. The activity was done with the objective of to determine the optimum application rate of NPSZn and Nitrogen fertilizers for yield and yield components of maize. The three levels of NPSZn $\left(75,100\right.$, and 125) $\mathrm{kg} \mathrm{ha}^{-1}$ were combined with three level of $\mathrm{N}\left(21.2,28.3\right.$, and 35.4) $\mathrm{kg} \mathrm{ha}^{-1}$ after deducting the amount of $\mathrm{N}$ found in NPSZN were used for the field experiments. Treatments were laid out in RCBD design with three replications. The highest grain yield (4359 $\mathrm{kg} \mathrm{ha}^{-1}$ ) was obtained from combined application of $75 \mathrm{~kg}$ NPSZn with $28.3 \mathrm{~kg} \mathrm{ha}^{-1}$ and nearly followed by (4348 kg ha-1) which obtained from combined application of $100 \mathrm{~kg}$ NPSZn with $35.4 \mathrm{~kg} \mathrm{ha}^{-1}$ whereas the lowest grain yield $\left(2475 \mathrm{~kg} \mathrm{ha}^{-1}\right)$ was obtained from plots treated without fertilizer. The highest grain yield (4359 $\left.\mathrm{kg} \mathrm{ha}^{-1}\right)$ and nearly followed (4348 $\mathrm{kg} \mathrm{ha}^{-1}$ ) was obtained from plots fertilized with the higher $\mathrm{N}$ application $(35.4 \mathrm{~kg})$. The result of partial budget analysis suggested that the higher marginal rate of return $(12822.71 \%)$ was obtained from the combined application of $100 \mathrm{~kg}$ NPSZn with $35.4 \mathrm{~kg} \mathrm{~N} \mathrm{ha}^{-1}$. Therefore, based on this result it can be concluded that the combined application of $100 \mathrm{~kg}$ NPSZn with $35.4 \mathrm{~kg} \mathrm{~N} \mathrm{ha}^{-1}$ can be recommended in the study areas and for other similar agro-ecologies it can be agronomically optimum and economically affordable levels to increase improved maize production.
\end{abstract}

Keywords: NPSZn, Nitrogen, Fertilizer rate, Yield, Yield components, Maize

DOI: $10.7176 / \mathrm{JNSR} / 12-10-03$

Publication date:May $31^{\text {st }} 2021$

\section{INTRODUCTION}

Maize (Zea mays L) is one of the most important cereal crops throughout the world. It is used as feed for animals, food for human and raw material in industries. Maize is the third most important cereal after wheat and rice globally and the most widely distributed (Siwale J. et al., 2009). Maize is one of the most important crops grown in Ethiopia (Mosisa et al., 2007). It is a major crop in Ethiopia in production, consumption and income generation for both resource constrained men and women. In Ethiopia, maize is first in productivity and second in area coverage after teff (CSA, 2018/19). The national area coverage and average yield of maize is $18.60 \%$ (about 2,367,797.39 hectares) and 30.08\% (94,927,708.34 quintals) respectively. The area coverage and average yield of maize in Oromia regional state is 1,324,274.98 hectares and 54,383,119.44 Quintals respectively (CSA, 2018/19).

However, there are a number of factors which are responsible for the low production and productivity of maize. Among these factors, inappropriate crop nutrition management and poor soil fertility are the most important factors responsible for low yield of maize (Shah et al., 2009). The low productivity of maize is also due to inappropriate cropping systems, mono-cropping, nutrient mining, unbalanced nutrient application, removal of crop residues from the fields and inadequate re-supplies of nutrients have contributed to decline in crop yields (McDonald et al., 2005). Low soil fertility is highly affects the growth and development of maize as compared to other crops. As a result, it is often said "maize speaks" implying that maize cannot produce maximum yields unless sufficient nutrients are available (Delorite et al., 1967). When the soil does not supply sufficient nutrients for normal plant growth application of supplemental nutrients are required. The proper application rates of plant nutrients are determined by knowledge about the nutrient requirement of the crop and the nutrient supplying power of the soil (Foth et al., 1997). However, yield levels obtained by small scale farmers remained stagnant despite the availability of improved varieties (Benti Tolessa, 1993). It has been estimated that at least 30 to $50 \%$ of crop yield increment is attributable to application of commercial fertilizers (Stewart et al., 2005). Like in other developing countries, information on soil fertility status is not adequate to meet the requirement of agricultural development programs, rational fertilizer promotions and recommendations based on actual limiting nutrients for a given crop in Ethiopia. The prevailing blanket fertilizer rate 
recommendation throughout the country on all soil types and agro ecological zone justifies the existence of little information on the fertility status of Ethiopia's soils.

Nitrogen is a most important and crucial major nutrient and it is very important for maize and other cereal crops. Nitrogen is important for the plant metabolism as it participates of proteins and chlorophyll biosynthesis, being necessary since the early phenological stages of the plant development (Basso et al., 2000), and participates in several major metabolic pathways of plants biochemistry (Andrade et al., 2003). Under appropriate levels of other nutrients in the soil, nitrogen provides the greatest increment to maize yield (Coelho, 2004). Nitrogen in essential for carbohydrates uses within plants and stimulates root and development as well as the uptake of other nutrients (Khan et al., 2014). Deficiency of nitrogen results in low plant growth which reduces the grain yield, leaf area index, leaf area duration and rate of photosynthesis. It imparts dark green color to plants.

Phosphorus has many essential functions in plant life; its role in energy storage and transfer is singly the most important. Large quantity of Phosphorus is found in seed and it is considered essential for seed formation. Phosphorus is essential for grain formation; ripening and reproductive parts of maize plant (Stangel et al., 1994). It needed for growth, nucleus formation, photosynthesis, utilization of sugar and starch, cell division and fat and albumen formation. Phosphorus is readily translocated within the plants and it moves from older tissues to younger tissues (Ali et al., 2002). Phosphorus in adequate amount is necessary for earlier maturity, rapid growth and improves the quality of vegetative growth. Deficiency of phosphorus is responsible for small ears in maize due to crooked and missing rows as (Masood et al., 2011).

Maize also needs some micro nutrients for its better growth and higher yield such as zinc. Zinc applications are reported to increase maize grain yield around world (Harris et al., 2007). Zinc also plays a very important role in plant better growth. Although zinc required in small quantity for crops but if there is zinc deficiency then it can with hold plant growth. For quality of edible parts of crop, for enhancement of yield and zinc concentration in plants, $\mathrm{Zn}$ is extensively used (Wang et al., 2012). Zinc plays role in metabolic functions and also it increase protein content in grain because it helps in protein synthesis in grain. Zinc can also increase the plumpness of grain which results in better yield of crop.

To overcome the constraint of low nutrient recovery and optimize fertilizer use, there is need to replace such general and over-simplistic fertilizer recommendations with those that are rationally differentiated according to agro-ecological zones (soils and climate), crop types, nutrient uptake requirements and socioeconomic circumstances of farmers. Better matching fertilizer application recommendations to local climate, soil, and management practices helps ensure that production can be intensified in a cost-effective and sustainable way and, thereby, enhance regional food security.

Trials carried out in many localities across Ethiopia also recommend different rates of $\mathrm{P}$ and $\mathrm{N}$ in accordance to crop and soil types (Inc Ho et al,. 1992). Increasing yields through the application of nitrogen and phosphorus alone can deplete other nutrients (FAO, 2000). However, crop productivity can also be limited because of toxicity and/or deficiency of essential plant nutrients. To avert this situation the Ministry of Agriculture of the country has recently introduced a new compound fertilizer NPSZn which containing Nitrogen, Phosphorous, Sulfur and Zinc with the ratio of $17.7 \% \mathrm{~N}-35.3 \% \mathrm{P} 2 \mathrm{O} 5+6.5 \% \mathrm{~S}+2.5 \% \mathrm{Zn}$ that can substitutes DAP in Ethiopian agriculture. Nevertheless, little information is available on NPSZn fertilizer requirement including macro and micro plant nutrients. NPSZn was recommended for 18 kebeles of Fadis district of Eastern Hararghe Zone (ATA, 2015). Thus, it became relevant to evaluate the responses of maize to the newly introduced NPSZn fertilizer and nitrogen rates in the study area and to track economic and agronomic optimum rates of its application. Therefore the objective of this study was to determine the optimum application rate of NPSZn and Nitrogen fertilizers for yield and yield components of maize.

\section{MATERIALS AND METHODS}

\subsection{Area description}

The experiment was conducted at Boko research station and Balina Arba on farmer's field in the Fedis district of Eastern Hararge of Oromia regional state during the 2018/19 and 2019/20 consecutive cropping season under rain fed condition. Fedis district has latitude between $8^{\circ} 22^{\prime}$ ' and $9^{\circ} 14^{\prime}$ 'North and longitude between $42^{\circ} 02^{\prime}$ and $42^{\circ} 19^{\prime}$ East, in middle and low land areas: altitude range is from $1200-1600 \mathrm{~m}$.a.s.l, with a prevalence of low lands. The district receives average annual rainfall of $400-804 \mathrm{~mm}$; the minimum and maximum air temperature of $20-25^{\circ} \mathrm{c}$ and $30-35^{\circ} \mathrm{c}$, respectively.

\subsection{Experimental design and treatments}

The experiments were consisting total of ten treatments including control (without fertilizer). Urea was used as source of $\mathrm{N}$ though the amount of $\mathrm{N}$ found in NPSZn was considered in order to determining the amount of $\mathrm{N}$ required from urea. The three levels of NPSZn $\left(75,100\right.$, and 125) $\mathrm{kg} \mathrm{ha}^{-1}$ were combined with three level of $\mathrm{N}$ $\left(21.2,28.3\right.$, and 35.4) $\mathrm{kg} \mathrm{ha}^{-1}$ after deducted the amount of $\mathrm{N}$ found in NPSZN. The treatment combinations of 
NPSZn and UREA after deducting the amount of $\mathrm{N}$ found in the NPSZn was as the following table.

Table 1: The combinations of NPSZn and UREA after deducting the amount of $\mathrm{N}$ found in the NPSZn.

\begin{tabular}{|ccc|}
\hline No. & NPSZn $\left(\mathbf{k g ~ h a} \mathbf{~}^{-1}\right)$ & UREA $\left(\mathbf{k g ~ h a}^{\mathbf{- 1}}\right)$ \\
\hline 1 & 0 & 0 \\
\hline 2 & 75 & 46.09 \\
\hline 3 & 75 & 61.52 \\
\hline 4 & 75 & 76.96 \\
\hline 5 & 100 & 46.09 \\
\hline 6 & 100 & 61.52 \\
\hline 7 & 100 & 76.96 \\
\hline 8 & 125 & 46.09 \\
\hline 9 & 125 & 61.52 \\
\hline 10 & 125 & 76.96 \\
\hline
\end{tabular}

A full dose of NPSZn fertilizer was applied at planting time, while $\mathrm{N}$ fertilizer was applied at knee height period for the $\mathrm{N}$ adjusted. The plot size was $3 \times 3 \mathrm{~m}\left(9 \mathrm{~m}^{2}\right)$ and the net harvested plot area was $90 \mathrm{~m}^{2}$. The spacing between replications and plots were 1 and $0.5 \mathrm{~m}$, respectively. The intra and inter row spacing were $25 \mathrm{x} 75 \mathrm{~cm}$, respectively. Seed of improved Melkasa-2 maize variety was sown for both locations with the recommended seed rate of $25 \mathrm{~kg} \mathrm{ha}^{-1}$ at depth of $10 \mathrm{~cm}$. All recommended cultural practices (plowing, digging and weeding) for the test crop was done as per the recommendation of the area.

\subsection{Soil sampling and analysis}

Soil samples was collected randomly from 0-30 cm depth from the experimental field before planting, the soil samples was collected from the entire area using a zigzag sampling technique. A Disturbed of composite soil sample was taken to laboratory for physico-chemical properties analysis. The sample was analyzed for soil $\mathrm{pH}$, Total Nitrogen (TN), Organic Matter (OM), Available Phosphorus and Electrical Conductivity (EC) at Bedele soil research center following standard analytical procedures.

\subsection{Crop data collection and Analysis}

The plant and plot basis data was recorded from the three central rows out of the five rows per plot. The data collected include plant height $(\mathrm{cm})$, days to $50 \%$ (tasseling and silking), days to $90 \%$ maturity, number of cobs per plant, cob length $(\mathrm{cm})$, number of kernel rows per cob, hundred grain weight $(\mathrm{g})$ and grain yield per hectare $(\mathrm{kg})$ were collected.

Plant height $(\mathrm{cm})$ of five randomly selected plants per plot was measured from ground level to the point where the tassel started branching and the mean value was taken as plant height. Days to 50\% (tasseling and silking) and 90\% physiological maturity of the crop was recorded when the plants in the plot reached to their respective phonological stages. The number of cobs of five randomly taken plants was counted from the central three rows of each plot and the average was recorded. Cob length was measured from five randomly selected plants per plot after harvest and the average value was recorded for each plot. The number of kernel rows per cob was counted on five representative ears and the average value was recorded for each plot. Hundred grain weights was determined by counting and weighing from the bulk of shelled grain at $12.5 \%$ moisture level and expressed in grams for each plot. Grain yield was determined by harvesting the entire net plot area and converted into kilogram per hectare.

The collected data were subjected to statistical analysis of variance (ANOVA) using Genstat $15^{\text {th }}$ edition. Significant difference between and among treatment means were assessed using the least significant difference (LSD) at 5\% level of probability.

\section{RESULTS AND DISCUSSION}

\subsection{Physicochemical Properties of Soil}

Soil samples collected and analyzed from the experimental fields before planting for some selected soil properties (Table 2). 
Table 2: Physical and chemical properties of soil in the experimental sites before planting

\begin{tabular}{|lllll|}
\hline Soil Property & Boko & Balina Arba & Discribtion & Reference \\
Soil texture (\%) & 28 Sand & 32 Sand & & \\
& 48 clay & 50 clay & Clay & \\
\hline pH & 24 silt & 18 silt & & \\
\hline TN (\%) & 7.95 & 7.85 & Slightly alkaline & \\
\hline OM (\%) & 0.09 & 0.08 & Low & Tekalign, 1991 \\
\hline Ava. P (ppm) & 2.84 & 3.46 & High & Tekalign, 1991 \\
\hline CEC (meq/100g) & 1.27 & 1.2 & Very low & Olsen et al., 1954 \\
\hline
\end{tabular}

Where $\mathrm{pH}$-power of hydrogen, $\mathrm{TN}=$ Total nitrogen, $\mathrm{OM}=$ Organic matter, Ava. $\mathrm{P}=$ Available phosphorus, $\mathrm{E} . \mathrm{C}=$ Electrical conductivity and $\mathrm{CEC}=$ Cation exchange capacity

The soils sampled from sites of Boko and Balina Arba were dominated by clay textural class having an approximately average proportion of sand (28\%), clay (48\%) and silt contents $(24 \%)$, and sand (32\%), clay $(50 \%)$ and silt contents $(18 \%)$, respectively (Table 2). The average $\mathrm{pH}$ value of soils of the study sites were 7.95 and 7.85 for Boko and Balina Arba respectively (Table 2). The average $\mathrm{pH}$ of sampled soil was fall in the rating of moderately alkaline at both study locations. The surface soil of the study areas exhibited an average Soil electrical conductivity (EC) of 1.19 and $1.37(\mathrm{mmhos} / \mathrm{cm})$ for Boko and Balina Arba, respectively. Soil organic matter (OM) contents of the study sites were 2.84 and $3.46 \%$, respectively for Boko and Balina Arba (Table 2). The average value of total nitrogen contents of the soils of the study sites of Boko and Balina Arba were 0.09 and $0.08 \%$, respectively (Table 2 ). The average available phosphorus of soils of the study sites were measured with 1.27 and $1.2 \mathrm{ppm}$ for the sites of Boko and Balina Arba, respectively (Table 2). The Cation exchange capacity (CEC) contents of the study sites were measured with values of 19.8 and 14.43 (meq/100g) for Boko and Balina Arba respectively.

\subsection{Crop Phenology, Growth, Yield and Yield Component Parameters}

The combined data analysis of variance (ANOVA) revealed that significance differences $(\mathrm{P}<0.05)$ and non significance differences $(\mathrm{P}<0.05)$ were observed among combined fertilizer application of NPSZn with nitrogen. Significance differences were recorded on days to $50 \%$ tasseling, days to $50 \%$ silking, days to $90 \%$ physiological maturity while, significance differences was not recorded on plant height (Table 3). The combined data analysis of variance also showed that significance variations were observed on number of cobs per plant, cob length, number of kernel rows per cob and grain yield whereas significance differences was not observed on hundred grain weight (Table 4).

Table 3: Combined mean squares from analysis of variance (ANOVA) of measured phenology and growth parameters

\begin{tabular}{llllll}
\hline & \multicolumn{5}{c}{ Mean Square } \\
\hline Source of variation & d. f. & DT & DS & DM & PH \\
\hline Replication & 2 & 10.08 & 2.48 & 2.03 & 950.5 \\
Treatment & 9 & $12.60^{* *}$ & $42.75^{* *}$ & $17.95^{* *}$ & $291.30 \mathrm{~ns}$ \\
Year & 1 & $728.02^{* *}$ & $7631.02^{* *}$ & $720.00^{* *}$ & $7439.10^{* *}$ \\
Location & 2 & $598.53^{* *}$ & $258.13^{* *}$ & $842.70^{* *}$ & $4664.60^{* *}$ \\
treatment*Year & 9 & $4.80^{*}$ & $27.07 \mathrm{~ns}$ & $4.14 \mathrm{~ns}$ & $53.50 \mathrm{~ns}$ \\
treatment*Location & 18 & $1.74 \mathrm{~ns}$ & $3.28 \mathrm{~ns}$ & $1.61 \mathrm{~ns}$ & $29.60 \mathrm{~ns}$ \\
Error & 48 & 2.25 & 15.08 & 4.24 & 179 \\
Mean & & 70.11 & 86.61 & 127.2 & 155.5 \\
LSD & & 1.42 & & 1.95 & 12.68 \\
CV $(\%)$ & 2.1 & & 1.6 & 8.6 \\
\hline
\end{tabular}

* Significant, $* *$ highly significant at $5 \%$ probability level, where, CV-coefficient, ns $=$ none significant, $\mathrm{Df}=$ degree of freedom, DT= days to tasseling, DT= days to Silking, DM= days to physiological maturity, $\mathrm{PH}=\mathrm{plant}$ height 
Table 4: Combined mean squares from analysis of variance (ANOVA) of measured yield and yield component parameters

\begin{tabular}{lllllll}
\hline & \multicolumn{7}{c}{ Mean Square } \\
\hline Source of variation & d. f. & CPP & CL & KRPC & HGW & GYha-1 \\
\hline Replication & 2 & 0.48 & 1.17 & 2.84 & 63.51 & 5372192 \\
Treatment & 9 & $1.30^{* *}$ & $13.46^{* *}$ & $8.30^{* *}$ & $16.36 \mathrm{~ns}$ & $1732650^{* *}$ \\
Year & 1 & $0.67^{*}$ & $16.70^{* *}$ & $8.02^{*}$ & $766.05^{* *}$ & $24466136^{* *}$ \\
Location & 2 & $0.01 \mathrm{~ns}$ & $7.42^{*}$ & $0.03 \mathrm{~ns}$ & $104.53^{* *}$ & $5808253^{*}$ \\
treatment*Year & 9 & $0.40^{*}$ & $1.31 \mathrm{~ns}$ & $1.65 \mathrm{~ns}$ & $4.38 \mathrm{~ns}$ & $1001613 \mathrm{~ns}$ \\
treatment*Location & 18 & $0.084 \mathrm{~ns}$ & $1.65 \mathrm{~ns}$ & $0.70 \mathrm{~ns}$ & $1.83 \mathrm{~ns}$ & $454190 \mathrm{~ns}$ \\
Error & 48 & 0.12 & 1.94 & 2.1 & 11.65 & 1185323 \\
Mean & & 1.422 & 16.6 & 13 & 23.8 & 3840 \\
LSD & & 0.33 & 1.32 & 1.4 & 3.23 & 984.3 \\
CV $(\%)$ & & 24.3 & 8.4 & 11.3 & 14.4 & 27 \\
\hline
\end{tabular}

* Significant, $* *$ highly significant at $5 \%$ probability level, where, $\mathrm{CV}$-coefficient, $\mathrm{ns}=$ none significant, $\mathrm{Df}=$ degree of freedom, $\mathrm{CPP}=$ number of cobs per plant, $\mathrm{CL}=$ cob length, $\mathrm{KRPC}=$ number of kernel rows per cob, $\mathrm{HGW}=$ hundred grain weight, GY kg ha ${ }^{-1}=$ grain yield $(\mathrm{kg} / \mathrm{ha})$

\subsubsection{Plant Height}

Analysis of variance showed that there were no significant variations $(p \leq 0.05)$ among the combined fertilizer rates of NPSZn with $\mathrm{N}$ on plant height. However there was significantly increased plant height as compared to the control (unfertilized plots). The taller combined mean of plant height $(161.00 \mathrm{~cm})$ was recorded from plots fertilized with $100 \mathrm{~kg}$ NPSZn in combination with $35.4 \mathrm{~kg} \mathrm{~N} \mathrm{ha}^{-1}$ whereas the shortest plant height was recorded from plots without fertilizer (Table 5). This result implied that even though there is no significant difference among combined fertilizer rates, plant height is more responsive to highest $\mathrm{N}$ rate. The result showed that plant height increased as $\mathrm{N}$ rate increased, this could be attributed to a more fact that higher rates of nitrogen may have caused rapid cell division and elongation. The tallest plant height recorded at highest $\mathrm{N}$ rate might be nitrogen has beneficial effect on plant metabolism which affects physiological process of the crop and thereby increases the growth parameters (Jeet et al., 2012). Nitrogen helps in maize plant growth \& zinc helps in enzymes metabolism and faster cell divisions, cell elongation and ultimately increases plant height. The increment in plant height is due to the nitrogen usage by plants in active cell division to form building blocks for cell expansion (Ullah et al., 2015). Similarly, Chimdessa, (2016) also reported that application of blended fertilizer was significantly increased plant height as compared to the recommended NP fertilizers and the control. Similarly more vegetative development by nitrogen resulted in increased mutual shading and intermodal expansion (Asif et al., 2013).

Table 5: Combined mean values of days to 50\% tasseling, 50\% silking, $90 \%$ maturity and plant height of Maize

\begin{tabular}{lllll}
\hline Treatment & PH & DT & DS & DM \\
\hline 0NPSZnX0N & $141.80 \mathrm{~b}$ & $73.22 \mathrm{c}$ & $91.67 \mathrm{c}$ & $130.80 \mathrm{~b}$ \\
$75 N P S Z n X 21.2 \mathrm{~N}$ & $160.80 \mathrm{a}$ & $69.56 \mathrm{ab}$ & $85.89 \mathrm{ab}$ & $127.20 \mathrm{a}$ \\
$75 N P S Z n X 28.3 \mathrm{~N}$ & $153.40 \mathrm{ab}$ & $69.89 \mathrm{ab}$ & $87.44 \mathrm{ab}$ & $127.40 \mathrm{a}$ \\
$75 N P S Z n X 35.4 \mathrm{~N}$ & $157.40 \mathrm{a}$ & $70.00 \mathrm{ab}$ & $86.22 \mathrm{ab}$ & $127.00 \mathrm{a}$ \\
$100 N P S Z n X 21.2 \mathrm{~N}$ & $158.30 \mathrm{a}$ & $68.78 \mathrm{a}$ & $84.67 \mathrm{a}$ & $126.00 \mathrm{a}$ \\
$100 N P S Z n X 28.3 \mathrm{~N}$ & $154.4 \mathrm{ab}$ & $70.00 \mathrm{ab}$ & $86.22 \mathrm{ab}$ & $125.70 \mathrm{a}$ \\
$100 N P S Z n X 35.4 \mathrm{~N}$ & $161.00 \mathrm{a}$ & $70.11 \mathrm{ab}$ & $85.33 \mathrm{ab}$ & $126.80 \mathrm{a}$ \\
$125 N P S Z n X 21.2 \mathrm{~N}$ & $158.10 \mathrm{a}$ & $69.44 \mathrm{ab}$ & $85.00 \mathrm{a}$ & $127.40 \mathrm{a}$ \\
$125 N P S Z n 28.3 \mathrm{~N}$ & $158.00 \mathrm{a}$ & $69.67 \mathrm{ab}$ & $84.89 \mathrm{a}$ & $126.20 \mathrm{a}$ \\
$125 N P S Z n X 35.4 \mathrm{~N}$ & $151.60 \mathrm{ab}$ & $70.44 \mathrm{~b}$ & $88.78 \mathrm{bc}$ & $127.40 \mathrm{a}$ \\
\hline Mean & 155.5 & 70.11 & 86.61 & 127.2 \\
LSD & 12.68 & 1.421 & 3.68 & 1.95 \\
CV $(\%)$ & 8.6 & 2.1 & 4.5 & 1.6 \\
\hline
\end{tabular}

Where, means followed by the same letters are not significantly different $(\mathrm{P} \leq 0.05), \mathrm{CV}$-coefficient of variance, NS-non-significance

\subsubsection{Days to $50 \%$ Tasseling}

The results of analysis of variance showed that there was significant difference $(\mathrm{P} \leq 0.05)$ among combined fertilizers rates on days to 50\% tasseling. Early tasseling (68.78 days) was recorded with plots fertilized with 100 $\mathrm{kg}$ NPSZn in combination with $21.2 \mathrm{~kg} \mathrm{~N}^{-1}$ whereas the longest days to $50 \%$ tasseling (73.22 days) was recorded for unfertilized plots (Table 5). Combined fertilizer application of $100 \mathrm{~kg}$ NPSZn with $21.2 \mathrm{~kg} \mathrm{~N} \mathrm{ha}^{-1}$ hastened days to tasseling by 4.44 days as compared to the control. The result suggested that availability of sufficient nutrient in the soil for plant uptake promoted vigorous vegetative growth and development of the 
plants. This decrease in days to tasseling with the combined application of NPSZn with N fertilizer might be attributed to the impact of positive interaction with other nutrients. It was observed that NPSZn with different rates of nitrogen might have encouraged early establishment, rapid growth and development of crop thus; shortening the days to tasseling. This may be due to the effect of fertilizers on tasseling of maize. Similarly, Bakala (2018) found that 50\% tasseling to be significantly affected by the application of blended fertilizer rates.

\subsubsection{Days to 50\% Silking}

Silking of maize was significantly affected $(\mathrm{P} \leq 0.05)$ by combined fertilizer application of NPSZn with N. Early silking (84.67 days) was recorded with plots fertilized with $100 \mathrm{~kg}$ NPSZn in combination with $21.2 \mathrm{~kg} \mathrm{~N} \mathrm{ha}^{-1}$ (Table 5). However, the maximum number of days to attain silking (91.67 days) was observed under control (unfertilized) plots (Table 4). The result showed that combined fertilizer application of $100 \mathrm{~kg}$ NPSZn with 21.2 $\mathrm{kg} \mathrm{N} \mathrm{ha}{ }^{-1}$ hastened days to silking by seven days as compared to control. This implies the combination of NPSZn with $\mathrm{N}$ fertilizer might have encouraged early establishment, rapid growth and development of crop thus; shortening the days to silking. The other reason could application of $\mathrm{N}$ fertilizer applied at different rate to all treatment of NPSZn fertilizer and thus effect of N was significant. Our result was similar with, Dagne (2016) who found that days to silking were significantly affected by the application of blended fertilizers. Bakala (2018) also found that $50 \%$ silking, tasseling and maturity to be significantly affected by the application of blended fertilizer.

\subsubsection{Days to $90 \%$ Maturity}

The result suggested that, days to $90 \%$ physiological maturity were significantly affected $(\mathrm{P} \leq 0.05)$ by combined fertilize rates of NPSZn and N. The combined fertilizer application of NPSZn and N rate has significantly reduced days to maturity as compared to the control. Early maturity (126 days) was recorded with the plots fertilized with $100 \mathrm{~kg} \mathrm{NPSZn}$ in combination with $21.2 \mathrm{~kg} \mathrm{~N}^{-1}$ (Table 5). Accordingly, the maximum days to attained $90 \%$ physiological maturity (130.8 days) was recorded under unfertilized plots (Table 4). Compared to the control, mean values of days to maturity was decreased by five days due to the rate of $100 \mathrm{~kg} \mathrm{NPSZn} \mathrm{ha}^{-1}$ combined with the rate of $21.2 \mathrm{~kg} \mathrm{~N}^{-1}$. The result showed that combined fertilizer application of NPSZn with $\mathrm{N}$ was related with rapid growth and hastened maturity of maize, this might be due to the presence of $\mathrm{Zn}$ fertilizer in the NPSZn blended fertilizer. In conformity with the results obtained from this study, Bakala (2018) found that days to $50 \%$ maturity to be significantly affected by the application of blended fertilizer rates.

\subsubsection{Number of Cobs per Plant}

The mean values and analysis of combined fertilizer of NPSZn and N on number of kernel rows per cob revealed significant difference $(\mathrm{p} \leq 0.05)$ among fertilizers rates. The maximum combined mean of number of cobs per plant (2.01) was recorded from combined application of $100 \mathrm{~kg}$ NPSZn with $35.4 \mathrm{~kg} \mathrm{~N} \mathrm{ha}{ }^{-1}$ while, the low number of cobs per plant (1.00) was recorded for control plots (Table 6). The result showed that increasing NPSZn level from 0 to $100 \mathrm{~kg} \mathrm{ha}^{-1}$ and $\mathrm{N}$ level from 0 to $35.4 \mathrm{~kg} \mathrm{ha}^{-1}$ significantly increased the number of cobs per plant from 1.00 to 2.00 . This implied that combined fertilizer of $100 \mathrm{~kg}$ NPSZn and $35.4 \mathrm{~kg} \mathrm{~N} \mathrm{ha}^{-1}$ increased number of cobs per plant by $50 \%$ over the control plots. The result was corroborated by the findings of Matusso, (2014) who reported that increasing nitrogen level from 50 to $300 \mathrm{~kg}$ ha-1 significantly increased the number of ears per plant from 1.2 to 2.05 .

\subsubsection{Cob Length}

The combined fertilizer rate of NPSZn and $\mathrm{N}$ was significantly influenced $(\mathrm{p} \leq 0.05)$ cob length. The taller combined mean of cob length $(18.04 \mathrm{~cm})$ was recorded from combined application of $100 \mathrm{~kg}$ NPSZn with 35.4 $\mathrm{kg} \mathrm{ha}^{-1}$ while, the shortest cob length $(13.48 \mathrm{~cm})$ was recorded from the control treatment (Table 6). The result showed that as NPSZn increased from 0 to 100 and $\mathrm{N}$ increased from 0 to $35.4 \mathrm{~kg} \mathrm{ha}^{-1}$, cob length increased from 13.48 to $18.04 \mathrm{~cm}$. Similarly, combined fertilizer rate of NPSZn and N increased cob length by $25.28 \%$ over the control treatments. The cob length increment with the combination of NPSZn and N fertilizer might be attributed to good photo assimilate supply. The maximum assimilate supply should be available during maize grain filling (Arif et al., 2010). The two to three week period after 50\% silking as critical stage in the development of maize that is highly dependent on assimilate supply; the period when final kernel number is determined (Haney et al., 2015).

\subsubsection{Number of kernel rows per cob}

The combined data analysis of variance showed that there was significant difference $(\mathrm{p} \leq 0.05)$ among fertilizers rates on number of kernel rows per cob. The highest combined mean on number of kernel rows per cob (14.00) was recorded from combined application of h $100 \mathrm{~kg} \mathrm{NPSZn}$ with $21 \mathrm{~kg} \mathrm{~N} \mathrm{ha}^{-1}$ whereas the lowest number of kernel rows per cob (10.67) was recorded for control (unfertilized treatment) (Table 6). The result showed that as NPSZn increased from 0 to 100 and $\mathrm{N}$ increased from 0 to $21.2 \mathrm{~kg} \mathrm{ha}^{-1}$, the number of kernel rows per cob increased from 10.67 to 14 . This indicated that compared to the control treatment, mean values of number of kernel rows per cob was increased by $23.8 \%$ due to the combined fertilizer application of NPSZn and N. 
Table 5: Combined mean of number of cobs per plant, cob length, number of kernel rows per cob, hundred grain weight and grain yield

\begin{tabular}{|c|c|c|c|c|c|}
\hline Treatment & CPP & $\mathrm{CL}(\mathrm{cm})$ & KRPC & $\mathrm{HGW}(\mathrm{g})$ & GY $\left(\mathrm{kgha}^{-1}\right)$ \\
\hline 0NPSZnX0N & $1.00 \mathrm{~d}$ & $13.48 \mathrm{c}$ & $10.67 \mathrm{c}$ & $20.86 b$ & $2475 \mathrm{a}$ \\
\hline $75 \mathrm{NPSZnX} 21.2 \mathrm{~N}$ & $1.11 \mathrm{~cd}$ & $16.15 b$ & $13.78 \mathrm{a}$ & $23.7 \mathrm{ab}$ & $3727 b$ \\
\hline $75 N P S Z n X 28.3 \mathrm{~N}$ & $1.11 \mathrm{~cd}$ & $16.89 \mathrm{ab}$ & $12.22 \mathrm{~b}$ & $24.11 \mathrm{a}$ & $4240 b$ \\
\hline 75NPSZnX35.4N & $1.56 \mathrm{~b}$ & $17.07 \mathrm{ab}$ & $13.78 \mathrm{a}$ & $24.87 \mathrm{a}$ & $4359 b$ \\
\hline $100 N P S Z n X 21.2 \mathrm{~N}$ & $1.01 \mathrm{~d}$ & $16.74 \mathrm{ab}$ & $14.00 \mathrm{a}$ & $23.46 \mathrm{ab}$ & $4061 b$ \\
\hline 100NPSZnX28.3N & $1.56 \mathrm{~b}$ & $16.59 \mathrm{~b}$ & $12.89 \mathrm{ab}$ & $22.8 \mathrm{ab}$ & $3492 \mathrm{ab}$ \\
\hline $100 N P S Z n X 35.4 \mathrm{~N}$ & $2.01 \mathrm{a}$ & $18.04 \mathrm{a}$ & $12.89 \mathrm{ab}$ & $24.08 \mathrm{ab}$ & $4348 b$ \\
\hline $125 \mathrm{NPSZnX} 21.2 \mathrm{~N}$ & $1.56 \mathrm{~b}$ & $17.28 \mathrm{ab}$ & $12.67 \mathrm{ab}$ & $24.97 \mathrm{a}$ & $3447 \mathrm{ab}$ \\
\hline $125 \mathrm{NPSZnX} 28.3 \mathrm{~N}$ & $2.00 \mathrm{a}$ & $16.81 \mathrm{ab}$ & $12.89 \mathrm{ab}$ & $23.2 \mathrm{ab}$ & $4136 b$ \\
\hline 125NPSZnX35.4N & $1.333 \mathrm{bc}$ & $17.41 \mathrm{ab}$ & $13.11 \mathrm{ab}$ & $25.68 \mathrm{a}$ & $4118 b$ \\
\hline Mean & 1.422 & 16.6 & 13 & 23.8 & 3840 \\
\hline LSD & 0.3269 & 1.32 & 1.4 & 3.23 & 984.3 \\
\hline CV $(\%)$ & 24.3 & 8.4 & 11.3 & 14.4 & 27 \\
\hline
\end{tabular}

Where, Where, means followed by the same letters are not significantly different $(\mathrm{P} \leq 0.05), \mathrm{CV}$-coefficient of variance, NS-non-significance, CPP- Cop per plant, $\mathrm{CL}$ - Cob length, $\mathrm{KRPC}=$ kernels row per cob, GY- Grain yield, HGW- Hundred grain weight

\subsubsection{Hundred Grain Weight}

The result of analysis of variance showed that there was no significant difference $(\mathrm{P} \leq 0.05)$ among fertilizers rates on hundred grain weight of maize. However the highest combined mean value of hundred grain weight $(25.68 \mathrm{~g})$ was obtained from combined application of $125 \mathrm{~kg}$ NPSZn with $35.4 \mathrm{~kg} \mathrm{~N} \mathrm{ha}^{-1}$ while, the lowest $(20.86$ g) was obtained from untreated (control) plots (Table 6). The combined mean value of hundred grain weight was increased by $18.77 \%$ as compared to the control. The result showed that hundred grain weight increased from 20.86 to $25.68 \mathrm{~g}$ as NPSZn increased from 0 to 125 and $\mathrm{N}$ increased from 0 to $35.4 \mathrm{~kg} \mathrm{ha}^{-1}$. Finally the heavier grains and more hundred grains weight were achieved from the highest rate of NPSZn and N. This implied the direct or indirect effects of nutrients in the NPSZn and N attributed positive interaction on hundred grain weight and other morphological and physiological parameters of maize. The production of more assimilates as a result of the synergistic effect of nitrogen and zinc finally formed heavier grains and more thousand grains weight was achieved. It is the imperative yield dependent parameter. It expresses the magnitude of seed formation and development. Tariq et al. (2002) also presented that maize yield factors and yield was positively amplified by zinc application. Sharar et al. (2003) had confirmed that on this trait there was influential effect of zinc along with nitrogen as well.

\subsubsection{Grain Yield}

Analysis of variance showed that there were significant differences $(p \leq 0.05)$ among the combined fertilizer rates of NPSZn and N on grain yield. The highest grain yield (4359 $\mathrm{kg} \mathrm{ha}^{-1}$ ) was obtained from combined application of $75 \mathrm{~kg}$ NPSZn with $28.3 \mathrm{~kg} \mathrm{ha}^{-1}$ and nearly followed by (4348 $\mathrm{kg} \mathrm{ha}^{-1}$ ) which obtained from combined application of $100 \mathrm{~kg}$ NPSZn with $35.4 \mathrm{~kg} \mathrm{ha}^{-1}$ whereas the lowest grain yield $\left(2475 \mathrm{~kg} \mathrm{ha}^{-1}\right)$ was obtained from plots treated without fertilizer (Table 6). Combined mean of grain yield had 43.22\% yield advantage compared to the control treatment. The increase in grain yield was probably due to the encouragement in photosynthesis, rapid growth and formation of heavy green foliage by NPSZn and N effectiveness which in turn produced more yield. Application of NPSZn fertilizer increased total grain yield in combination with N doses. Our result was similar with (Coelho, 2004) findings who concluded that under appropriate levels of other nutrients in the soil, nitrogen provides the greatest increment to maize yield. Application of zinc increase total grain yield in combination with high nitrogen doses (Rafiq et al., 2010). Saeed et al. (2010) \& Mukhtar et al. (2011) stated grain total yield got affected by nitrogen.

\subsection{Partial Budget Analysis}

As it were presented in Tables 7, the net farm benefit was calculated taking possible field variable costs and grain yields benefits for the study areas. The maximum farm net benefit was 52748.9 ETB ha-1 obtained from the combined application of $75 \mathrm{~kg}$ NPSZn with $28.3 \mathrm{~kg} \mathrm{~N} \mathrm{ha}^{-1}$. The partial budget analysis revealed that the combined application of $100 \mathrm{~kg}$ NPSZn with $35.4 \mathrm{~kg} \mathrm{~N} \mathrm{ha}^{-1}$ was resulted in highest marginal rate of return with values of $12822.71 \%$. These values implied that with one ETB cost it was attained 128.23 ETB profit. Therefore, the combined application of $100 \mathrm{~kg}$ NPSZn with $35.4 \mathrm{~kg} \mathrm{~N} \mathrm{ha}^{-1}$ can be recommended for the production of improved maize for the study areas. 
Table 7: Partial budget analysis of grain yield of maize under the effect of different combined NPSZn and N fertilizer rates for Boko.

\begin{tabular}{|lllllll|} 
Treatment & TVC & GYLD & AGYLD & TGYGR (ETB) & NB (ETB) & MRR\% \\
\hline 0NPSZnX0N & 0 & 2475 & 2227.5 & 31185 & 31185 & \\
\hline 75NPSZnX21.2N & 1730.65 & 3727 & 3354.3 & 46960.2 & 45229.55 & 811.52 \\
\hline 75NPSZnX28.3N & 1952.5 & 4240 & 3816 & 53424 & 51471.5 & 2813.59 \\
\hline 100NPSZnX21.2N & 2086.65 & 4061 & 3654.9 & 51168.6 & 49081.95 & $\mathrm{D}$ \\
\hline 75NPSZnX35.4N & 2174.5 & 4359 & 3923.1 & 54923.4 & 52748.9 & 4174.10 \\
\hline 100NPSZnX28.3N & 2308.5 & 3492 & 3142.8 & 43999.2 & 41690.7 & $\mathrm{D}$ \\
\hline 125NPSZnX21.2N & 2442.65 & 3447 & 3102.3 & 43432.2 & 40989.55 & $\mathrm{D}$ \\
\hline 100NPSZnX35.4N & 2530.5 & 4348 & 3913.2 & 54784.8 & 52254.3 & 12822.71 \\
\hline 125NPSZnX28.3N & 2664.5 & 4136 & 3722.4 & 52113.6 & 49449.1 & $\mathrm{D}$ \\
\hline 125NPSZnX35.4N & 2886.5 & 4118 & 3706.2 & 51886.8 & 49000.3 & $\mathrm{D}$ \\
\hline
\end{tabular}

Where, $\mathrm{TVC}=$ total variable cost, $\mathrm{GY}=$ grain yield, $\mathrm{ADGY}=$ adjusted grain yield, $\mathrm{TGYGR}=$ total grain yield gross return, $\mathrm{NB}=$ net benefit, $\mathrm{MRR}=$ marginal rate of return, $\mathrm{ETB}=$ Ethiopian birr, $\mathrm{D}=$ dominated.

N. B. Urea=14.38 ETB $/ 1 \mathrm{~kg}, \mathrm{NPSZn}=14.24 \mathrm{ETB} / 1 \mathrm{~kg}$, maize grain=14ETB $/ 1 \mathrm{~kg}$.

\section{SUMMARY AND CONCLUSION}

According to the combined mean analysis combined fertilizer rates of NPSZn and N revealed significance difference on grain yield. The highest grain yield (4359 kg ha-1) and nearly followed $\left(4348 \mathrm{~kg} \mathrm{ha}^{-1}\right)$ was obtained from plots fertilized with the higher $\mathrm{N}$ application rate $(35.4 \mathrm{~kg})$. Combined fertilizer application of $75 \mathrm{NPSZn}$ $\mathrm{kg}$ with $35.4 \mathrm{~N} \mathrm{~kg} \mathrm{ha}^{-1}$ was produced the highest grain yield and closely followed by combined fertilizer application of 100 NPSZn kg with $35.4 \mathrm{~N} \mathrm{~kg} \mathrm{ha}^{-1}$. The result of partial budget analysis suggested that the higher marginal rate of return (12822.71\%) was obtained from the combined application of $100 \mathrm{NPSZn} \mathrm{kg}$ with $35.4 \mathrm{~N}$ $\mathrm{kg} \mathrm{ha}^{-1}$. Therefore, based on this result it can be concluded that the combined application of $100 \mathrm{~kg}$ NPSZn with $35.4 \mathrm{~kg} \mathrm{~N} \mathrm{ha}{ }^{-1}$ can be recommended in the study areas and for other similar agro-ecologies it can be agronomically optimum and economically affordable levels to increase improved maize production.

\section{ACKNOWLEDGEMENT}

The author acknowledges Oromia Agricultural Research Institute, Fadis Agricultural Research Center for financing and providing working facility. We would like also to thanks Fadis district bureau of agriculture for their assistance in facilitating our work. Our special thanks also go to Balina Arba village of Fadis district farmers who helped us in giving the farm land and managing our trial work.

\section{REFERENCE}

Ali,J., Bakht, J., Shafi, M., Khan, S. and Shah, W.A. (2002) Effect of N and P on Yield Components of Maize. Pakistan Journal of Agronomy, 1, 12-14. http://dx.doi.org/10.3923/ja. 2002.12.14 http://dx.doi.org/10.3923/ja.2002.12.14

Andrade, A. C., Fonseca, D. M., Queiroz, D. S., Salgado, L. T. and Cecon, P. R. 2003. Elephant grass nitrogen andpotassium fertilization (PennisetumpurpureumSchum. cv. Napier). Ciência e Agrotecnologia, Lavras, p. 1643-1651.

Arif, M., I. Amin, M. T. Jan, I. Munir 3, K. Nawab, N. U. Khan, and K. B. Marwat, 2010. Effect of Plant Population And Nitrogen Levels And Methods of Application on Ear Characters and Yield of Maize. Pakistan Journal of Botany, 42 (3): 1959-1967.

Asif, M., M.F. Saleem, S.A. Anjum, M.A. Wahid and M.F. Bilal, 2013. Effect of nitrogen and zinc on growth and yield of maize (Zea mays L.). J. Agric. Res., 51(4): 455-464.

ATA (Agricultural Transformation Agency), 2015. Soil Fertility Mapping and Fertilizer Recommendation in Ethiopia: Update of EthioSIS project and status of fertilizer blending plants 24-26 Hawasa, Ethiopia.

Bakala A (2018). Soil characterization and response of maize (Zea mays L.) to application of blended fertilizer types and rates in Asossa district, Western Ethiopia. Unpublished MSc Thesis, Haramaya University, Ethiopia.

Basso, C.J., Ceretta, C.A. 2000. Manejo do nitrogênio no milho em sucessãoa plantas de cobertura de solo,sob plantio direto. 2000. Revista brasileira de ciência do solo, 24:905-915.

Basso, C.J., Ceretta, C.A. 2000. Manejo do nitrogênio no milho em sucessãoa plantas de cobertura de solo,sob

Benti Tolessa, 1993. The need an objective of the 1stNational Maize Workshop. In: Proceedings of the $1^{\text {st }}$ National Maize Workshop of Ethiopia. 5-7 May, 1992, IAR and IMWIC, Addis Ababa, Ethiopia.

Chimdessa, D. (2016). Blended fertilizers effects on maize yield and yield components of Western Oromia, Ethiopia. Agriculture, Forestry and Fisheries, 5(5), 151-162. https://doi.org/10.11648/j.aff.20160505.13 
CSA (Central Statistical Agency of the Federal Democratic Republic of Ethiopia), 2019. Agricultural Sample Survey, 2018/19. Report on Area and production of major crops (Private Peasant Holdings, meher season). Statistical Bulletin 278. Vol. I, Addis Ababa, Ethiopia

Dagne Chimdessa, 2016. Blended Fertilizers Effects on Maize Yield and Yield Components of Western Oromia, Ethiopia. Agriculture, Forestry and Fisheries. Vol. 5, No. 5, 2016, pp. 151-162.

Delorite, R. J. and H. L. Ahlgren, 1967. Crop Production. (3rded). Prentice Hall,Inc., Englewood Cliffs, New Jersey. Different Phosphorous Level on the Yield and Yield Component of Maize. Sarhad Journal of Agriculture, 27, 167-170.Singh A. K., Singh G. R. and Dixit R. S., 1997. Influence of plant population and moisture regimes on nutrient uptake and quality of winter maize (Zea mays). Indian Journal of Agronomy. 42(1): 107-111.

FAO (Food and Agriculture Organization), 2000. Fertilizers and their use. International Fertilizer Industry Association. Food and Agriculture Organization of the United Nations Rome, Italy.

Foth, H. D. and B. G. Ellis, 1997. Soil Fertility, (2nded). Lewis Publishers, Boca Raton, Florida. 290p.

Haney, R. L., Haney, E. B., Smith, D. R. and White, M. J. (2015) Estimating Potential Nitrogen Mineralization Using the Solvita Soil Respiration System. Open Journal of Soil Science, 5, 319-323.

Harris D, Rashid A, Mira G, Arif M, Shah H (2007) 'On-farm'seed priming with zinc sulphate solution a costeffective way to increase the maize yields of resource-poor farmers. Field Crops Res 102:119-127

Ho, C. T., 1992. Results of fertilizer trials conducted on major cereal crops by ADD/NFIU. Joint Working Paper No. 43. Addis Ababa, Ethiopia. 83p.

Jeet, S., Singh, J. P., Kumar, R., Prasad, R. K., Kumar, P., Kumari, A., \& Prakash, P. (2012). Effect of nitrogen and sulphur levels on yield, economics and quality of QPM hybrids under dry land condition of eastern Uttarpradesh, India. Indian Journal of Agricultural

Khan, F., khan, S., Hussain, S., Fahad, S. and Faisal, S. (2014) Different Strategies for Maintaining Carbon Sequestration in Crop Lands. Scientia Agriculture, 2, 62-76.

Masood, T., Gul, R., Munsif, F., Jalal, F., Hussain, Z., Noreen, N., Khan, H. and Nasiruddin, K.H. (2011) Effect

Masood.,T.Naz,M.Javed, I. Ahmad, H. Ullah and M. Iqbal, 2014. Effect of short term supply of nitrogen and farm yard manure on maize growth and soil parameters. Archives of agronomy and soil science, 60(3): 337-347.

Matusso J (2014). Growth and Yield Response of Maize (Zea mays L.) to Different Nitrogen Levels in Acid Soil. Academy Research Journal Agriculture Sciences Research 4(2):35-44.

McDonald AH, Nicol JM (2005) Nematode parasites of cereals. In: Luc M, Sikora RA, Bridge J (eds) Plant parasitic nematodes in subtropical and tropical agriculture. CABI Publishing, Wallingford, pp: 131-191.

Mosisa W, Wonde A, Berhanu T, Legesse W, Alpha D, Tumassi A (2007). Performance of CIMMTY maize germplasm under low nitrogen soil conditions in the mid altitude sub humid agro ecology of Ethiopia. Afr. J. Sci. Conf. Proc. 18:15-18.

Mukhtar, T., M. Arif. S. Hussain, M. Tariq and K. Mehmood, 2011. Effect of different rates of nitrogen and phosphorus fertilizers on growth and yield of maize. J. Agric. Res., 49(3): 333-339. plantio direto. 2000. Revista brasileira de ciência do solo, 24:905-915.

Rafiq, M.A., A. Ali, M.A. Malik and M. Hussain, 2010. Effect of fertilizer levels and plant densities on yield and protein contents of autumn planted maize. Pak. J. Agri. Sci., 47(3): 201-208.

Saeed, M., A. Khaliq, Z.A. Cheema and A.M. Ranjha, 2010. Effect of nitrogen levels and weed-crop competition durations on yield and yield components of maize. J. Agric. Res., 48(4): 471-481. Sciences, 4(9), 31-38. doi: 5539/jas.v4n9p31

Shah, S., Talat, H., Zamir, M., Shahid, I., Waseem, M., Ali, A., \& Khalid, W. B. (2009). Growth and yield response of maize (Zea mays L.) to organic and inorganic sources of nitrogen. Pakistan Journal of Life Society Science, 7(2), 108-111.

Sharar, M.S., M. Ayub, M.A. Nadeem and N. Ahmad, 2003. Effect of different rates of nitrogen and phosphorus on growth and grain yield of maize. Asian J. Pl. Sci., 2(3): 347-349.

Siwale J, Mbata K, Microbert J and Lungu D. 2009. Comparative resistance of improved maize genotypes and landraces to maize weevil. African Crop Sci. J., 17(1):1-16.

Stewart, W. M., D. W. Dibb, A. E. Johnston and T. J. Smyth, 2005. The contribution of commercial fertilizer nutrients to food production. Agron J.97: 1-6.

Tariq, M., M.A. Khan and S. Perveen, 2002. Response of maize to soil applied zinc (Zn). Asian J. Pl. Sci., 1 (4): 476-477.

Ullah, M.I., A.A. Khakwani, M. Sadiq, I. Awan, M. Munir and Ghazanfarullah, 2015. Effects of nitrogen fertization rate on growth, quality and economic return of fodder maize (Zea mays L.). Sarhad J. agric., 31(1): 45-52.

Wang, J., H. Mao, H. Zhao, D. Huang and Z. Wanga, 2012. Different increases in maize and wheat grain zinc concentrations caused by soil and foliar applications of zinc in Loess Plateau, China. Elsevier J. Field Crops Research, 135: 89-96. 